To cite: A de Man 'The Sustainable Development Goals and the rights-based approach to development: Compatible or missing the point?' (2019) 19 African Human Rights Law Journal 445-469 http://dx.doi.org/10.17159/1996-2096/2019/v19n1a21

\title{
The Sustainable Development Goals and the rights-based approach to development: Compatible or missing the point?
}

\author{
Annelie de Man* \\ Coordinator, Advocacy Division, Free State Centre for Human Rights, \\ University of the Free State, South Africa \\ https://orcid.org/0000-0003-2026-5797
}

\section{Summary}

The Millennium Development Goals have been criticised for the limited role that human rights have played in their design and implementation. When the timeline for the achievement of the MDGs drew near the attention turned to formulating a new development compact that would succeed them. In order to address the critiques of the MDGs a rightsbased approach to development has been proposed to form the basis for the formulation, implementation and monitoring of the new set of goals. With the 2030 Agenda for Sustainable Development, and the 17 Sustainable Development Goals, adopted on 25 September 2015, it falls to be questioned to what extent the 2030 Agenda incorporates human rights in all stages of development programming. This article undertakes such an examination. To this end the article analyses to what extent the SDG framework is in line with the principles of a rights-based approach to development, namely, equality and non-discrimination, accountability, participation, empowerment and the interrelatedness of human rights. It concludes that although the 2030 Agenda in some areas is compatible with the principles of a rights-based approach to development, especially the principle of participation, more should be done with respect to the implementation, monitoring and evaluation of the SDGs to ensure that the full spectrum of advantages offered under a rights-based approach to development can be achieved.

* LLD (Free State); anneliedm@gmail.com 
Key words: rights-based approach to development; Sustainable Development Goals; human rights; equality and non-discrimination; participation; accountability; empowerment; interrelatedness and indivisibility

\section{Introduction}

Over the past few decades the focus of development practice and theory was on human development, which culminated in the Millennium Development Goals (MDGs) adopted in 2000. For the next 15 years the MDG framework took centre stage in international and national development agendas. However, despite its achievements the MDGs have since their adoption received a number of criticisms. Many of the critiques raised against the MDG agenda were based on the argument that human rights played a limited role in their design, implementation and monitoring. When the timeline for the achievement of the MDGs drew near, attention turned to formulating a new development compact that would succeed them.

On 25 September 2015 the United Nations (UN) General Assembly (UNGA) adopted the 2030 Agenda for Sustainable Development consisting of 17 new goals, coined the Sustainable Development Goals (SDGs). The newly-formulated goals encompassed the three pillars of sustainability, namely, economic, social and environmental development. ${ }^{1}$ The main objective of the SDGs, which came into force in January 2016, is to address new development priorities and challenges, as well as to close the gaps left by the MDGs. ${ }^{2}$ As with the original goals, the SDGs will be employed to inform national and international development priorities and action plans. ${ }^{3}$

1 AK Abashidze et al 'Achievement of Sustainable Development Goals (2016-2013): International legal dimension' (2016) 9 Indian Journal of Science and Technology 2 http://www.indjst.org/index.php/indjst/article/view/102168/73993 (accessed 13 February 2019); DR Kanter et al 'Translating the Sustainable Development Goals into action: A participatory backcasting approach for developing national agricultural transformation pathways' (2016) 10 Global Food Security 71; N Kumar et al 'Strategies for achieving the Sustainable Development Goals (SDGs) in South Asia: Lessons from policy simulations' (2016) United Nations Economic and Social Commission for Asia and the Pacific, South and South-West Asia Development Papers $16017 \mathrm{http}: / /$ www.unescap.org/sites/default/files/20160825_SDG\%20 PolicyStrategies\%20South\%20Asia_SSWA_DP_1601_final_for\%20upload.pdf (accessed 13 February 2019); AR Nunes et al 'The importance of an integrating framework for achieving the Sustainable Development Goals: The example of health and well-being' (2016) BMJ Global Health 1 http://gh.bmj.com/content/1/ 3/e000068 (accessed 13 February 2019); G Vaggi 'Making the Sustainable Development Goals work' (2016) 3 International Journal of Cooperation and Development 34 41; MA Rosen 'Sustainable development: A vital quest' (2017) 1 European Journal of Sustainable Development 210.

2 Transforming our World: The 2030 Agenda for Sustainable Development, adopted 25 September 2015 paras 16-17; Kumar et al (n 1) 7.

3 P Bergling \& S jin 'The new black on the development catwalk: Incorporating rule of law into the Sustainable Development Goals' (2015) 24 Washington International Law Journal Association 435. 
Under the umbrella of sustainable development, defined as 'development that meets the needs of the present without compromising the ability of future generations to meet their own needs', the framework of the SDGs aims to eradicate poverty by the end of 2030. ${ }^{4}$ Furthermore, sustainable development incorporates a multitude of disciplines, including 'science, engineering, environment, ecology, economics, business, sociology, [and] philosophy'. ${ }^{5}$ As aptly summarised, 'the ultimate goal of the SDGs is to promote a new world view and provide the beginnings of a plan to end poverty without imposing significant costs on earth's life support systems'. ${ }^{6}$

When the focus shifted to the formulation of a new development agenda that will follow the MDGs, various bodies of the UN, UN member states, international organisations, non-governmental organisations (NGOs), civil society, human rights and development practitioners, as well as scholars in a multitude of fields, called for the post-2015 agenda to be based on international human rights laws and principles. To this end a rights-based approach to development has been proposed to form the basis of the formulation, implementation and monitoring of the new set of goals. Following a rights-based approach to development when formulating and implementing development frameworks, such as the new post-2015 agenda, holds a number of advantages. It is also argued that the human rights framework provides the strongest and most accepted moral basis on which development can be based.

This article uses the term 'rights-based approach to development' which 'cover[s] any kind of rights and is locally determined as a result of power relations' as an umbrella term which specifically includes a human rights-based approach. The latter 'builds on the international normative system of rights and the obligations undertaken by (most) states, which makes possible a growing international consensus on the content of the rights and the corresponding responsibility of the dutyholders'. ${ }^{7}$ The difference between the two approaches can be described as follows: ${ }^{8}$

[A human rights-based approach] represent[s] a narrower focus (normatively and legally speaking), whilst arguably possessing a stronger moral claim to legitimacy. By contrast, the [RBA] represent a more broadbased focus (again, normatively and legally), thereby enabling appeals to a

$4 \quad$ World Commission on Environment and Development Our common future (1987) ch 2 para 1 http://www.un-documents.net/our-common-future.pdf (accessed 13 February 2019). See also Rosen (n 1) 2.

5 Rosen (n 1) 2.

6 O Gaffney 'Sustainable Development Goals: Improving human and planetary wellbeing' (2014) 82 Global Change 2023.

7 Eide quoted in D Banik 'Support for human rights-based development: Reflections on the Malawian experience' (2010) 14 The International Journal of Human Rights 3437.

$8 \mathrm{H}$ Miller 'Rejecting "rights-based approaches" to development: Alternative engagements with human rights' (2015) Journal of Human Rights 4 http://dx.doi. org/10.1080/14754835.2015.1103161 (accessed 13 February 2019). 
more expansive discourse of rights (which for instance may extend towards notions of citizenship).

The aim of the article is to analyse the content of the 2030 Agenda to determine to what extent it is in line with human rights standards in formulation, implementation and monitoring. In other words, the article investigates whether the 2030 Agenda is compatible with a rights-based approach to development or whether it fails to answer the various calls for a more human rights-friendly agenda as mentioned above. To this end, part 2 discusses some of the critiques raised against the MDGs from a human rights perspective. This is followed by an overview of the path leading to the formulation of the SDGs to demonstrate, on the one hand, the importance placed on human rights through this process and, on the other, the need for the final framework to be based on human rights. Part 4 explores the relationship between the SDGs and their predecessor, the MDGs, keeping in mind the critiques mentioned. The final part explores the compatibility of the SDG framework, in all its phases, and the foundational principles of a rights-based approach to development.

\section{Successes and failures of the Millennium Development Goals}

The creation of the MDGs offered the world a global compact on development priorities according to which the international community and individual states could model their respective development plans. As once stated by Bill Gates, the MDGs represent 'the best idea for focusing the world on fighting global poverty'. ${ }^{9}$ It has made development more political and central to the global discourse. ${ }^{10}$ The massive international support that the goals have galvanised has caused it to become viewed as a 'critical indicator of the international system's ability to set and follow through on practical targets for a partnership for development'. ${ }^{11}$ Between 2000 and 2015 the MDGs made significant advances in achieving its established targets. ${ }^{12}$ According to the UN, the implementation of the MDG framework has 'saved the lives of millions and improved

9 T Paulson 'Back in time: Bill Gates speaks at UN, 2008, on the Millennium Development Goals' 25 September 2012 http://www.humanosphere.org/globalhealth/2012/09/bill-gates-speaks-at-un-on-the-millennium-development-goals/ (accessed 13 February 2019).

10 NK Poku \& J Whitman 'The Millennium Development Goals: Challenges, prospects and opportunities' (2011) 32 Third World Quarterly 37.

11 G Schmidt-Traub 'The Millennium Development Goals and human rights-based approaches: Moving towards a shared approach' (2009) 13 The International Journal of Human Rights 72.

12 For the final list of progress made under the MDGs, see UN 'Millennium Development Goals Report' (2015) 4-7 http://www.un.org/millenniumgoals/ 2015_MDG_Report/pdf/MDG\%202015\%20rev\%20 (July\%201).pdf (accessed 17 February 2019). 
conditions for many more' ${ }^{13}$ Moreover, it placed the eradication of poverty centrally on the international development agenda.

However, when the period allocated for the achievement of the MDGs expired, many development challenges remained unaddressed, including significant levels of inequality and poverty. ${ }^{14}$ Even before the end of 2015 many academics and scholars expressed the need for a more inclusive, sustainable and effective development agenda to follow the MDG framework. ${ }^{15}$ From a human rights perspective various reasons were offered for some of the failings of the MDGs.

Even though it has been said that human rights and the MDGs have the same goals in mind, namely, to alleviate human suffering and increase human development, there are many significant differences between the two frameworks. ${ }^{16}$ Alston strongly argues that in reality the MDGs are capable of only giving expression to a limited number of economic, social and cultural rights, and only gives symbolic expression to civil and political rights. ${ }^{17}$ Moreover, MDG 1 speaks about poverty in general and does not address the root causes thereof. ${ }^{18}$ On the other hand, human rights adhere to a more 'holistic understanding of poverty and its structural causes' and perceive human development in its broadest sense. ${ }^{19}$ As already mentioned in the criticisms above, the focus of the MDGs is limited to improving certain human capabilities. Other dimensions of human development, namely, socio-cultural, political and protective capabilities, are overlooked. A development approach based on human rights not only incorporates the full spectrum of development capabilities, but also addresses the root causes of poverty and the lack of progress. Furthermore, when one studies the practical implementation of the goals, it is evident that there are many differences between the two frameworks. ${ }^{20}$ Aleyomi and Ise Olorunkanmi argue, and many authors agree, that national development policies and plans that are

13 UN (n 12) 4.

14 UNDP 'UNDP support to the implementation of Sustainable Development Goal 1' (2016) 3 http://www.undp.org/content/dam/undp/library/Sustainable\%20Develo pment/1_Poverty_Jan15_digital.pdf?download (accessed 17 February 2019).

15 See TC Glendinning 'Book review: Millennium Development Goals: Looking beyond 2015' (2013) 4 African Review of Economics and Finance 301.

16 P Nelson 'Human rights, the Millennium Development Goals, and the future of development cooperation' (2007) 35 World Development 2042; S Kuruvilla et al 'The Millennium Development Goals and human rights: Realizing shared commitments' (2012) 34 Human Rights Quarterly 148.

17 P Alston 'Ships passing in the night: The current state of the human rights and development debate seen through the lens of the Millennium Development Goals' (2005) 27 Human Rights Quarterly 760.

18 Nelson (n 16) 2046.

$19 \mathrm{M}$ von Engelhardt 'The Millennium Development Goals and human rights at 2010: An account of the Millennium Summit Outcome' (2010) 2 Goettingen Journal of International Law 1136. See also W van Ginneken 'Social protection, the Millennium Development Goals and human rights' (2011) 42 Institute for Development Studies Bulletin 115. 
formulated and implemented in line with human rights principles will reach a higher level of success than those under the MDGs. ${ }^{21}$

Moreover, goals and rights are theoretically different from each other: 22

Goals are distinctly utilitarian, calculated to maximise welfare gains, of which the disadvantages have been mentioned. Rights make a normative claim that human dignity entitles each person to certain kinds of treatment and to protection from others.

Nelson gives two examples of the differences between goals and rights. The first example relates to the notion of agency. In essence, human rights belong to an individual, although in some circumstances it may be conferred on a group. The MDGs, on the other hand, were ascribed to states and international organisations that negotiate and agree on their content. Individuals form the objects of the goals, and not agents who can demand their fulfilment. Rights, on the other hand, create correlating duties that an individual can demand to be fulfilled. ${ }^{23}$

Second, the targets set under the MDGs make them capable of being monitored, thereby providing a 'framework for accountability'. ${ }^{24}$ Nelson disagrees with this and holds that monitoring does not automatically result in accountability. Even though goals can be embedded in duties to make them mandatory, additional processes, consequences and sanctions have to be put in place, especially at the national level, to ensure that society is capable of holding governments accountable for their failures or inaction. ${ }^{25}$ On the other hand, legally-recognised rights carries with them an imbedded accountability framework. It is thus argued that the value that accountability processes under the human rights framework adds is of immense importance for the realisation of goals based on recognised rights. ${ }^{26}$

Although a number of criticisms have been raised against the MDG framework, the advances made towards human development have been immense. However, it is argued that if a rights-based approach to development had been followed, more of the MDGs would have been achieved. However, it should be borne in mind that as both frameworks share a number of challenges and have their own unique strengths, they can be used to mutually reinforce one another. It is recommended that drawing synergies between the two agendas, and

$21 \mathrm{MB}$ Aleyomi \& $\mathrm{JO}$ Ise Olorunkanmi 'Africa and the Millennium Development Goals: Constraints and possibilities' (2012) 5 Journal of Alternative Perspectives in the Social Sciences 5369.

22 Nelson (n 16) 2045.

23 As above.

24 Fukuda-Parr quoted in Nelson (n 16) 2045.

25 Nelson (n 16) 2045-2046.

26 Nelson (n 16) 2046; A Flynn-Schneider 'Inter-governmental organisations' (2014) 21 Human Rights Brief 1 http://digitalcommons.wcl.american.edu/cgi/viewcon tent.cgi?article $=1906 \&$ context=hrbrief (accessed 17 February 2019). 
stronger collaboration between development and human rights actors and organisations, will be the best way forward to enhance global human development. Therefore, it may be accepted that the adoption of an internationally-agreed development agenda can hold various advantages if the critiques and failings of the MDGs are effectively addressed. It therefore falls to be questioned whether the 2030 Agenda on Sustainable Development, adopted as the follow-up global development agenda to the MDGs, was able to overcome these defects and are better aligned with human rights.

\section{Formulation and content of the Sustainable Development Goals}

\subsection{Lead-up to the formulation of the Sustainable Development Goals}

During the 2012 Rio+20 UN Conference on Sustainable Development, based on a preparatory proposal by Colombia and Guatemala, it was agreed that a new set of global development goals should be formulated to follow the MDGs. ${ }^{27}$ In 2012 a UN Systems Task Team, consisting of 50 experts representing a number of UN bodies and international organisations, including academics, was established by the UN Development Programme (UNDP) and UN Department of Economic and Social Affairs to commence the drafting of the post2015 development agenda. ${ }^{28}$ The task team delivered its first report in July 2012, titled Realizing the Future We Want for All, which outlined the UN's vision on international development post-2015. ${ }^{29}$ In the report human rights are identified as one of the three foundational principles 'constitut[ing] the common, underlying elements necessary to address and resolve, through transformative change, the global trends and challenges that people will face in the post-2015 era' ${ }^{30}$ During July 2012 a High-Level Panel of Eminent Persons advising the UN Secretary-General on the post-2015 agenda was established. The Panel produced a report in May 2013 which proposed 12 goals and 54 targets based on five 'transformative shifts',

27 UN 'The future we want' (2012) Outcome document of the United Nations Conference on Sustainable Development - Rio+20 para 18 http://www.un.org/ disabilities/documents/rio20_outcome_document_complete.pdf (accessed 17 February 2019. See also Gaffney (n 6) 20; JH Knox 'Human rights, environmental protection, and the Sustainable Development Goals' (2015) 24 Washington International Law Journal Association 517 524; Vaggi (n 1) 38.

28 Bergling \& Jin (n 3) 437.

29 UN Systems Task Team on the post-2015 UN Development Agenda 'Realising the future we want for all' (2012) Report to the Secretary-General http://www.un.org/ millenniumgoals/pdf/Post_2015_UNTTreport.pdf (accessed 17 February 2019); L Saner Yiu \& R Saner 'Sustainable Development Goals and Millennium Development Goals: An analysis of the shaping and negotiation process' (2014) 36 Asia Pacific Journal of Public Administration 8992.

30 UN Systems Task Team on the post-2015 UN Development Agenda (n 29) para 57. See also paras $58 \& 59$. 
namely, (a) leave no one behind; (b) sustainability; (c) jobs and inclusive growth; (d) peace and institutions; and (e) global partnership. ${ }^{31}$ Unfortunately the report has been criticised for not addressing the structural causes of poverty. ${ }^{32}$

Running parallel to these two groups were highly-inclusive participatory and bottom-up processes organised by the UN. ${ }^{33}$ The unprecedented high number of UN consultations preceding the formulation of the goals is argued to represent 'the biggest consultation exercise the world has ever seen'. ${ }^{34}$ The outcome document of the Rio+20 conference, 'The future we want', recognised that people's opportunities 'to influence their lives and future, participate in decision making and voice their concerns were fundamental for sustainable development $t^{35}$ In order to make this a reality the outcome document called for an Open Working Group, consisting of 30 representatives from member states functioning under the auspices of the UNGA, to be established with the mandate of deciding on the processes that should be followed in formulating the post-2015 development goals. ${ }^{36}$ On 22 January 2013 the working group began a series of inclusive consultative and participatory processes. At the same time, and in order to formulate a 'peoplecentred, development agenda', the UNDP conducted their own consultation processes which included 11 thematic-based consultations, face-to-face surveying under the My World Survey with

31 UN High-Level Panel of Eminent Persons on the Post-2015 Development Agenda 'A new global partnership: Eradicate poverty and transform economies through sustainable development' (2013) 7-12 http://www.post2015hlp.org/wp-content/ uploads/2013/05/UN-Report.pdf (accessed 17 February 2019). See also $P$ Narayanan et al 'Re-imagining development: Marginalised people and the post2015 agenda' in T Thomas \& P Narayanan (eds) Participation pays: Pathways for post-2015 (2015) 139-140; Saner Yiu \& Saner (n 29) 102.

32 P Narayanan et al 'Re-imagining development: Marginalised people and the post2015 agenda' in Thomas \& Narayanan (n 31) 139.

33 See CE Brolan et al 'Back to the future: What would the post-2015 global development goals look like if we replicated methods used to construct the Millennium Development Goals?' (2014) 10 Globalization and Health 3 11; L Caprani 'Five ways the Sustainable Development Goals are better than the Millennium Development Goals and why every educationalist should care' (2016) 30 Management in Education 102.

34 Caprani ( $n$ 33) 102. See also X Li 'Soft law-making on development: The Millennium Development Goals and post-2015 development agenda' (2013) 10 Manchester Journal of International Economic Law 362 367; UN 'United Nations Summit on Sustainable Development 2015: Informal summary' (2015) 1https:// sustainabledevelopment.un.org/content/documents/8521Informal\%20Summary \%20-\%20UN\%20Summit\%20on\%20Sustainable\%20Development\%202015.pdf (accessed 18 February 2019); OHCHR 'Human rights and the 2030 Agenda for Sustainable Development' http://www.ohchr.org/EN/Issues/MDG/Pages/The2030 Agenda.aspx (accessed 9 October 2017).

35 UN (n 27) para 13. See also C Cazabat 'Integrating civil participation into sustainable development practice' (2016) 5 European Journal of Sustainable Development 2529.

36 Bergling \& Jin (n 3) 439; G MacNaughton \& DF Frey 'Decent work, human rights and the Sustainable Development Goals' (2016) 47 Georgetown Journal of International Law 607643. 
citizens of member states, electronic surveys, as well as consultations with political leaders, international organisations, civil society, businesses and scholars. ${ }^{37}$ Through these processes nearly 8,5 million votes regarding the development priorities that should be included in the post-2015 agenda were recorded. ${ }^{38}$

In September 2014 the Open Working Group presented their proposal on the SDGs to the UNGA. ${ }^{39}$ The outcomes of the abovementioned and various other UN processes formed the content of the UN Secretary-General's Synthesis Report, The Road to Dignity by 2030: Ending Poverty, Transforming All Lives and Protecting the Planet, presented to the UNGA in December 2014. ${ }^{40}$ This formed a 'conceptual guide for the remainder of the formulation process' by proposing six essential elements for the post-2015 agenda, namely, 'dignity, people, prosperity, planet, justice [and] partnership' ${ }^{41}$ The last mentioned document formed the basis of a series of intergovernmental negotiations on the proposed goals. 42

At the UN Sustainable Development Summit on 25 September 2015, 17 new international development goals, known as the SDGs, were adopted by UN member states under the 2030 Agenda for Sustainable Development. ${ }^{43}$ The adoption of the Agenda garnered renewed support from governments, high-level organisations and civil society towards the achievement of international development goals. $^{44}$

37 S Kumar et al 'Millennium Development Goals (MDGs) to Sustainable Development Goals (SDGs): Addressing unfinished agenda and strengthening sustainable development and partnership' (2016) 41 Indian Journal of Community Medicine 1-2. See also Sustainable Development Knowledge Platform 'Post-2015 process' https://sustainabledevelopment.un.org/post2015 (accessed 9 October 2017); Li (n 34) 367; Brolan et al (n 33) 3 11; UNDP 'World leaders adopt Sustainable Development Goals' 25 September 2015 http://www.undp.org/ content/undp/en/home/presscenter/pressreleases/2015/09/24/undp-welcomesadoption-of-sustainable-development-goals-by-world-leaders.html (accessed 9 October 2017); Caprani (n 33) 102; MacNaughton \& Frey (n 36) 643.

38 Cazabat (n 35) 29.

39 UN Open Working Group of the General Assembly on Sustainable Development Goals 'Open Working Group proposal for Sustainable Development Goals' (2014) https://sustainabledevelopment.un.org/content/documents/ 1579SDGs\%20Proposal.pdf (accessed 18 February 2019).

40 UNGA 'The road to dignity by 2030: Ending poverty, transforming all lives and protecting the planet' (2014) Synthesis report of the Secretary-General on the post-2015 agenda http://www.un.org/ga/search/view_doc.asp?symbol=A/69/700 \&Lang=E (accessed 18 February 2019).

41 Bergling \& Jin (n 3) 439. See also Vaggi (n 1) 41.

42 South African Institute of International Affairs 'Factsheet: The journey to the Sustainable Development Goals', http://www.saiia.org.za/news/factsheet-the-jour ney-to-the-sustainable-development-goals' (accessed 9 October 2017); Saner Yiu \& Saner (n 29) 103-104.

432030 Agenda (n 2).

44 See UN (n 34) 1. 


\subsection{Content of the $\mathbf{2 0 3 0}$ Agenda for Sustainable Development}

The 2030 Agenda for Sustainable Development consists of 17 goals, 168 targets and 241 indicators. ${ }^{45}$ The Agenda, which came into force on 1 January 2016, covers the three core dimensions of sustainability, namely, economic growth, social progress and environmental protection. ${ }^{46}$ According to the UNSG at the time, Ban-Ki Moon, the Agenda provides 'a to-do list for people and planet, and a blueprint for success'. ${ }^{47}$

The 17 goals have been grouped into five categories, namely (a) people; (b) planet; (c) prosperity; (d) peace; and (e) partnership. ${ }^{48}$ The first seven goals were formulated to address the gaps left by the MDGs and will require meeting basic human development needs. On the other hand, Goals 8 to 10 enhance 'common drivers and crosscutting issues that are essential to advance sustainable development across all of the dimensions'. In addition, Goals 11 to 15 are focused on enhancing environmental sustainability, while Goals 16 and 17 aim to utilise a global partnership for development and the implementation of the goals. ${ }^{49}$ The main slogan of the goals is to leave no one behind, which emphasises the special focus that must be placed on the most vulnerable and marginalised in society. ${ }^{50}$ It is proposed that the Agenda is people-centred with a focus on human rights and social justice. Some view the Agenda as transformative in nature as it 'seek[s] to end poverty and hunger once and for all, while safeguarding the planet'. ${ }^{51}$ Moreover, under the Agenda the interrelatedness and indivisibility of the goals and the need to pursue all the goals in a comprehensive manner are acknowledged. 52

45 See 2030 Agenda (n 2); UNGA 'Final list of proposed Sustainable Development Goal indicators' (2016) Report of the Inter-Agency and Expert Group on Sustainable Development Goal Indicators https://sustainabledevelopment.un.org/ content/documents/11803Official-List-of-Proposed-SDG-Indicators.pdf (accessed 18 February 2019).

462030 Agenda (n 2) para 2. See also M Hajer et al 'Beyond cockpit-ism: Four insights to enhance the transformative potential of the Sustainable Development Goals' (2015) 7 Sustainability 1651 1652; J Kercher \& C Mahler 'Sustainable Development Goals: An opportunity for the realisation of human rights in and by Germany (2015) 1 http://www.ssoar.info/ssoar/handle/document/43813(accessed 18 February 2019); Kumar et al (n 1) 9; D Nabarro 'Transforming our world: How sustainable development will help us achieve zero hunger' in International Food Policy Research Institute et al (eds) 2016 Global hunger index: Getting to zero hunger (2016) 23.

47 K Willis 'Viewpoint: International development planning and the Sustainable Development Goals (SDGs)' (2016) 38 International Development Planning Review 105.

48 In accordance with the UNSG's 2014 Synthesis report (n 40). See also 2030 Agenda (n 2) Preamble; Vaggi (n 1$) 41$.

49 Kumar et al (n 1) 9-11.

502030 Agenda (n 2) para 4.

51 Nabarro (n 46) 23. See also UN (n 34) 1.

522030 Agenda (n 2) Preamble, paras 5, 17, 18 \& 55. See also UN (n 34) 1-2; Nabarro (n 46) 24. 
The SDGs are viewed as universally applicable development goals. However, it is the primary responsibility of each member state to adapt the goals to their own national contexts. ${ }^{53}$ Article 55 of the Agenda clearly states that

[t]argets are defined as aspirational and global, with each government setting its own national targets guided by the global level of ambition but taking into account national circumstances. Each government will also decide how these aspirational and global targets should be incorporated into national planning processes, policies and strategies.

In contrast to the MDG framework the 2030 Agenda places equal obligations on both developed and developing countries.55 Furthermore, due to its broad and inclusive nature, the co-operation of all stakeholders across a variety of sectors, whether at local, regional or international level, is required to ensure the success of the goals. ${ }^{56}$

The Agenda also provides a number of guidelines for follow-up and review processes. According to the Agenda, review processes will be conducted on a voluntary basis, be country-led and will take account of local contexts, realities, respective capacities and resources as well as levels of development. Respect must be given to national policy space and priorities and account must be given to the three dimensions of sustainable development. Global progress, including means of implementation, must also be monitored. Importantly, monitoring and review processes must be 'open, inclusive, participatory and transparent' as well as 'people-centred, gendersensitive, respect human rights and have a particular focus on the poorest, most vulnerable and those furthest behind'.57 Furthermore, the Agenda makes provision for a High-Level Political Forum on Sustainable Development to act under the authority of the UN Secretary-General and the UN Economic and Social Council (ECOSOC), with the task of 'reviewing global progress, identifying lessons learned, providing recommendations and guidance, and identifying emerging issues and trends' ${ }^{58}$ In order to assist with these processes the Agenda calls for '[q]uality, accessible, timely and reliable disaggregated data ... to ensure that no one is left behind'. ${ }^{59}$

53 UN (n 34) 1 9; 2030 Agenda (n 2) para 55; Caprani (n 33) 103; Kanter et al (n 1) 71; M Mesnard \& W Hynes 'New approaches to economic challenges and the Sustainable Development Goals: The way forward' in P Love (ed) Debate the issues: New approaches to economic challenges (2016) 164; Nabarro (n 46) 24. See also Hajer et al ( $n$ 46) 1652.

542030 Agenda (n 2) para 55.

55 Kercher \& Mahler (n 46) 1; 2030 Agenda (n 2) para 2; Nabarro (n 46) 23.

56 Nunes et al (n 1) 1.

572030 Agenda (n 2) paras 74(d) \& (e).

58 Nabarro (n 46) 27.

592030 Agenda (n 2) paras $48 \& 74(\mathrm{~g})$. 


\section{Comparison between the Millennium Development Goals and Sustainable Development Goals}

The MDGs played a significant role in placing development, including human development, at the centre of international politics. ${ }^{60}$ However, the goals faced a number of criticisms and failed to reach all its chosen targets. One of the main objectives in formulating the SDGs and their targets was to address the development challenges not included under the MDG framework. These include issues of climate change, increasing inequality and universal peace and justice. ${ }^{61}$ Moreover, the UNDP has stated that compared to the MDG framework '[t]he SDGs have a more ambitious agenda, seeking to eliminate rather than reduce poverty'. ${ }^{62}$ The UNDP claims that the SDGs 'go much further than the MDGs, addressing the root causes of poverty and the universal need for development that works for all people ... The [SGDs] will now finish the job of the MDGs, and ensure that no one is left behind. ${ }^{\prime 63}$ Furthermore, the UN Office of the High Commissioner for Human Rights (OHCHR) stated that the 2030 Agenda 'provides a transformative vision for people and planetcentred, human rights-based, and gender-sensitive sustainable development', unlike the narrow vision of development followed under the MDG framework. ${ }^{64}$ However, it should be borne in mind that the SDGs have the advantage of building on the lessons learned under the MDGs and carrying forward the development successes already achieved. ${ }^{65}$

A number of differences between the two agendas can be identified. The top-down and closed-off approach followed in the formulation of the MDGs was put aside for the more inclusive processes and people-centred strategies followed in the drafting of the SDG agenda. This has the potential of establishing a stronger sense of ownership by development actors, as well as the beneficiaries of development projects based on the SDGs. Moreover, the 2030 Agenda offers a larger role to the private sector and civil society in development processes. ${ }^{66}$ Whereas the MDGs focused only on the obligations of developing countries, the SDGs, also known as the Global Goals, are applicable to all countries. ${ }^{67}$ As already stated, the

60 See Vaggi (n 1$) 40$

61 UNDP (n 37); Kumar et al (n 37) 2.

62 UNDP (n 37).

63 UNDP Pakistan '2030 Agenda for Sustainable Development' http:// www.pk.undp.org/content/pakistan/en/home/post-2015/sdg-overview.html (accessed 10 October 2017).

$64 \mathrm{OHCHR}$ (n 34).

65 Kumar et al (n 37) 2.

66 Brolan et al (n 33) 11; Kercher \& Mahler (n 46) 2; Caprani (n 33) 103; Kumar et al (n 37) 2-3.

67 OHCHR (n 34); Gaffney (n 6) 20; Kercher \& Mahler (n 46) 1; 2030 Agenda (n 2) para 55; Nabarro (n 46) 23. See also Willis ( $n$ 47) 107-110. 
new framework also places an equal burden an all countries towards the global achievement of the goals. Furthermore, the MDGs mainly focused on achieving quantitative targets, ignoring the quality of progress achieved. The SDG framework requires the achievement of qualitative standards, in addition to its quantitative targets and indicators. ${ }^{68}$ As a good example, the targets and indicators under the education goal of both frameworks can be compared (Goal 2 of the MDGs and Goal 4 of the SDGs).

The 17 SDGs also can be perceived as much broader than the preceding eight MDGs. However, some view the large number of goals as too widespread, incapable of being effectively monitored and measured, as well as a non-continuation of the simplicity of the original framework. ${ }^{69}$ Others view the SDGs as overlapping and overly ambitious compared to its predecessors. ${ }^{70}$ However, it has been argued that the SDGs are much more comprehensive than the original goals. This not only relates to the increased number of goals and targets. ${ }^{71}$ For example, SDG 5, 'Achieve gender equality and empower all women and girls', goes much further than the mere obligation of promotion of gender equality under the MDGs. The goal under the SDG framework also includes targets related to violence against women and girls; unpaid domestic and care work; forced marriages; gender mutilation; and equal access to economic and political resources. ${ }^{72}$ The SDGs also give expression to all types of human rights, including civil and political rights, which were not sufficiently addressed under the MDG framework. ${ }^{1 / 3}$ The OHCHR has stated that the SDG framework gives a clearer recognition of human rights and, unlike its predecessor, is grounded in international human rights law. ${ }^{74}$ However, the SDG framework holds one significant advantage over the MDGs. Under the MDG framework progress was limited to a certain number of individuals or percentage of society. The aim of the SDGs, on the other hand, is to ensure progress for all and achieve the global eradication of poverty.

68 Caprani (n 33) 103.

69 Caprani (n 33) 102; Nunes et al (n 1) 1-2; Willis (n 47) 106.

70 Vaggi (n 1$) 42$.

71 A Jha et al 'Accelerating achievement of the Sustainable Development Goals: A game changer in global health' (2016) 352 The British Medical Journal 1 https:// sustainabledevelopment.un.org/content/documents/969226_Jha_Accelerating\% 20achievement\%20of\%20the\%20sustainable\%20development\%20goals.pdf (accessed 18 February 2019); Willis (n 47) 107. 


\section{Agenda for Sustainable Development and rights-based approaches to development}

As mentioned, when the time came to start looking beyond the MDGs time frame, many agreed that human rights should play a central role in the formulation and implementation of the next global development agenda. Various critiques have been raised against the human rights framework, the most important of which, for this discussion, is that of the 'universality' of human rights. ${ }^{75}$ This critique holds that human rights, as contained in the Universal Declaration of Human Rights (Universal Declaration), ${ }^{76}$ dictates liberal, Western values, and no space is allowed for 'multi-culturalism', 'relativism', or 'contextualism'.77 It is argued that as a product of the Enlightenment era, the human rights framework is inevitably contextualised within in an essentially Western and modernist framework. ${ }^{78}$ Against this critique it may be argued that concepts of human dignity and worth, the notion that everyone should be treated according to a certain minimum standard, and ideas regarding respect for others are included in a number of other religious, philosophical and cultural ideologies, including Judaism, Islam, Buddhism, Hinduism and Christianity, and in Greek, Arabic and Indian philosophy. ${ }^{79}$ Moreover, through the principle of participation a rights-based approach to development aims to take account of local beliefs, traditions and cultures so as not to impose foreign values on local communities. Many agree that human rights are seen as universal moral values with distinctive legal, moral and political components. Even though various critiques have been raised against the high moral standing of human rights, individuals, organisations and governments from a variety of political beliefs, cultures and ideologies have globally accepted the values contained in the international human rights framework as the highest moral authority. ${ }^{80}$

Various academics have also expressed their support for the adoption of a rights-based approach to development under the 2030 Agenda. ${ }^{81}$ For example, Alston argues that following a rights-based

75 For an in-depth discussion of these critiques, see A de Man 'Critiques of the human rights framework as a foundation for a human rights-based approach to development' (2018) 43 Journal for Juridical Sciences 84.

76 UNGA 'Universal Declaration of Human Rights' adopted 10 December 1948.

77 C Brown 'Universal human rights: A critique' (1997) 1 The International Journal of Human Rights 41 54; S Hopgood The end times of human rights (2013) 19.

78 J Ife Human rights and social work. Towards rights-based practice (2008) 5. For a full analysis of this argument, see M Freeman Human rights: An interdisciplinary approach (2011) 119-155.

79 Miller (n 8) 7.

80 See eg ME Winston The philosophy of human rights (1989) v; R Cruft et al 'The philosophical foundations of human rights: An overview' in R Cruft et al (eds) Philosophical foundations of human rights (2015) 1.

81 E Dorsey 'Falling short of our goals: Transforming the Millennium Development Goals into millennium development rights' (2010) 28 Netherlands Quarterly of 
approach to development can overcome many of the failures of the MDG framework, thereby ensuring the most effective post-2015 agenda. ${ }^{82}$ Abashidze et al argue that the formulation of national goals, targets and strategies as well as the duties of different role players, whether in the public or private sphere, should be framed in accordance with the international human rights obligations of respective states. ${ }^{83}$ As stated by Amnesty International: ${ }^{84}$

Any new framework should address discrimination comprehensively, establish global and national targets and timelines to fulfil minimum essential levels of economic, social and cultural rights for all, and ensure that there are effective national and international accountability mechanisms to monitor the realisation of goals aimed at addressing poverty and exclusion and to provide redress for failures to respect and promote human rights.

In 2012 the UN Task Team called for the formulation of the post-2015 agenda to be based on equality, human rights and sustainability. ${ }^{85}$ Moreover, at the 2012 Rio+20 conference UN member states confirmed their intention to develop post-2015 goals that are in accordance with international human rights law. ${ }^{86}$ This was further acknowledged in a 2013 statement by 332 civil society organisations that called for the post-2015 agenda to be based on 'the inherent dignity of people as human rights-holders, [and] domestic governments as primary duty-bearers' ${ }^{\prime}{ }^{87}$ The joint statement further called for the empowerment of individuals to hold duty-bearers accountable, including under the international human rights legal system, and for the agenda to be based on the core human rights principles of universality, transparency, participation, equality, nondiscrimination and accountability. ${ }^{88}$ The Chairpersons of the UN human rights treaty bodies also confirmed in 2013 that sustainable development in the post-2015 era would require the explicit

Human Rights 516 519-521; Van Ginneken (n 19) 115; A Caliari 'Analysis of Millennium Development Goal 8: A global partnership for development' (2014) 15 Journal of Human Development and Capabilities: A Multi-Disciplinary Journal for People-Centred Development 275-276.

82 P Alston 'A human rights perspective on the Millennium Development Goals' (2004) Paper prepared as a contribution to the work of the Millennium Project Task Force on Poverty and Economic Development para $23 \mathrm{http}: / /$ pacific. ohchr.org/docs/A_HR_perspective_on_MDGs_P_Alston.doc (accessed 18 February 2019).

83 Abashidze et al (n 1) 3-4.

84 Amnesty International 'Combating exclusion: Why human rights are essential for the MDGs' (2010) 7 SUR International Journal for Human Rights 5571 . See also Schmidt-Traub (n 11) 80.

85 UN Systems Task Team (n 29) 58-64.

86 UN (n 27) para 7. See also Kercher \& Mahler (n 46) 2.

87 Joint statement by 332 civil society organisations 'Human rights for all post-2015' 10 December 2013 https://sustainabledevelopment.un.org/content/documents/ 5123joint.statement.dec10.pdf (accessed 18 February 2019). See also MacNaughton \& Frey (n 36) 644-645.

As above. 
recognition of the link between development and human rights. ${ }^{89}$ Moreover, Ban-Ki Moon, UN Secretary-General from 2007 to 2016, on a number of occasions has confirmed the importance of human rights for development. This includes statements in his 2014 Synthesis Report and the 2013 report to the UNGA where he calls for a followup framework that is 'a far-reaching vision of the future firmly anchored in human rights and universally accepted values and principles, including those encapsulated in the UN Charter, the Universal Declaration of Human Rights, and the Millennium Declaration'.90 Unfortunately, the Secretary-General has been criticised for missing the opportunity to clearly illustrate how existing human rights obligations can be incorporated into the development arena. ${ }^{91}$

Following a rights-based approach to development in all stages of development programming holds various advantages for development projects. These include strengthened accountability measures; the provision of explicit guidelines and benchmarks through authoritative interpretation of rights; the provision of a holistic view of human development; and ensuring equitable and sustainable progress. Moreover, a rights-based approach to development in several ways gives explicit expression to the Declaration on the Right to Development (RTD Declaration). ${ }^{92}$ The foundational principles of rights-based approaches, namely, equality and non-discrimination, accountability, participation, indivisibility and interrelatedness of human rights are mentioned throughout the RTD Declaration.

Bearing in mind the principles of a rights-based approach to development and the benefits that can be achieved when this approach is followed, it may be argued that formulating and implementing the post-2015 global development agenda in line with a rights-based approach to development is the best possible means of giving effect to the abovementioned calls, statements and arguments. Therefore, it should be examined to what extent all phases of the 2030 Agenda, which includes formulation, implementation, monitoring and evaluation, are guided by human rights standards that are in line with a rights-based approach to development.

Under this approach development goals must thus be formulated in line with international human rights laws and obligations. In terms of the final set of goals and targets under the 2030 Agenda, a group of

89 MacNaughton \& Frey (n 36) 645-646.

90 UNGA 'A life of dignity for all: Accelerating progress towards the Millennium Development Goals and advancing the United Nations development agenda beyond 2015' (2013) Report of the Secretary-General para 75 http://www.un.org/ millenniumgoals/pdf/A\%20Life\%20of\%20Dignity\%20for\%20All.pdf (accessed 18 February 2019). See also Knox (n 27) 517 524; MacNaughton \& Frey (n 36) 644.

91 Knox (n 27) 526.

92 UNGA 'Declaration on the Right to Development' adopted 4 December 1986. 
civil society organisations has stated that 'the goals and targets are consistent with existing human rights standards in some quite significant ways'. ${ }^{93}$ According to Kercher and Maler the majority of goals correspond with existing human rights, for example Goal 4 and the right to education, and Goal 3 and the right to health. ${ }^{94}$ Governments have also emphasised the strong links between the SDGs and human rights, as can be seen from the following excerpts from the 2030 Agenda: ${ }^{95}$

We envisage a world of universal respect for human rights and human dignity, the rule of law, justice, equality and non-discrimination; of respect for race, ethnicity and cultural diversity; and of equal opportunity permitting the full realisation of human potential and contributing to shared prosperity. ${ }^{96}$

The new Agenda is guided by the purposes and principles of the Charter of the United Nations, including full respect for international law. It is grounded in the Universal Declaration of Human Rights, international human rights treaties, the Millennium Declaration and the 2005 World Summit Outcome Document. It is informed by other instruments such as the Declaration on the Right to Development. ${ }^{97}$

In doing so, we reaffirm our commitment to international law and emphasize that the Agenda is to be implemented in a manner that is consistent with the rights and obligations of states under international law. 98

We reaffirm the importance of the Universal Declaration of Human Rights, as well as other international instruments relating to human rights and international law. We emphasise the responsibilities of all states, in conformity with the Charter of the United Nations, to respect, protect and promote human rights and fundamental freedoms for all, without distinction of any kind as to race, colour, sex, language, religion, political or other opinion, national or social origin, property, birth, disability or other status. ${ }^{99}$

However, according to the UN 2003 Common Understanding, development goals and targets must be based on international standards and aimed directly towards the protection and fulfilment of human rights as contained in the Universal Declaration and other international human rights instruments. Unfortunately, some view the goals as 'underwhelming' in their expression of human rights

93 As quoted in Knox (n 27) 525.

94 Kercher \& Mahler ( $n$ 46) 2.

$95 \mathrm{UN}$ (n 34) 1.

962030 Agenda (n 2) para 8.

972030 Agenda para 10.

982030 Agenda para 18.

992030 Agenda para 19. 
principles. ${ }^{100}$ It is further argued that none of the goals is explicitly framed in terms of human rights. ${ }^{101}$ This is a significant failure concerning a rights-based approach to development and represents a missed opportunity to clearly outline the respective obligations of the different duty bearers in achieving the various SDGs. As a result one is left to question to what extent the other development phases of the 2030 Agenda are in line with the principles espoused under a rightsbased approach to development, in order to ensure the maximum level of success under the SDG framework.

\subsection{Equality and non-discrimination}

Under international human rights law everyone has the right to be treated equally and without unfair distinction. When following a rights-based approach to development duty bearers have the responsibility to identify and address inequalities, discriminatory practices and unjust distributions of power and resources that underlie development challenges. ${ }^{102}$ To the extent that the 2030 Agenda gives expression to human rights in the formulated SDGs, it explicitly holds that all goals and targets are universally applicable to all countries, developed and developing alike. ${ }^{103}$

With its bold mission statement of 'leave no one behind', the 2030 Agenda highlights the need to focus development objectives and strategies on all human beings. ${ }^{104}$ Moreover, by requiring disaggregated data to monitor and review progress, the Agenda ensures that the vulnerable and marginalised are included in all phases of development. Therefore, the 2030 Agenda goes much further than the MDGs, which required targets to be achieved for only a certain percentage of the population. Furthermore, under the original goals progress was only expressed in terms of national or global averages, leaving significant monitoring gaps.

On the other hand, the SDGs have been criticised for being too vague to provide useful practical guidance. ${ }^{105}$ For instance, goals and targets related to non-discrimination refer only to the reduction of inequality in general and fail to mention specific groups that might be more vulnerable to discrimination in certain contexts, such as

100 MacNaughton \& Frey (n 36) 662. See also T Pogge \& M Sengupta 'The Sustainable Development Goals (SDGs) as drafted: Nice idea, poor execution' (2015) 24 Washington International Law Journal Association 571 576; Knox (n 27) 525 536; Abashidze et al (n 1) 3.

101 Pogge \& Sengupta (n 100) 576-577; MacNaughton \& Frey (n 36) 663.

102 OHCHR 'Frequently asked questions on a human rights-based approach to development cooperation' UN Publications: Geneva 20068 http://www.ohchr. org/Documents/Publications/FAQen.pdf (accessed 18 February 2019).

1032030 Agenda (n 2) paras 5 \& 55.

1042030 Agenda (n 2) para 4.

105 Knox (n 27) 536. 
indigenous groups that are more likely to be harmed by environmental changes. ${ }^{106}$ This can hamper adherence to the principle of equality and non-discrimination as required under a rights-based approach to development.

\subsection{Accountability}

A rights-based approach to development empowers individuals to make use of local mechanisms, whether political, administrative, judicial or quasi-judicial, to hold duty bearers accountable for their respective human rights and development obligations. ${ }^{107}$ Moreover, a rights-based approach to development creates the opportunity for actors, other than the state, such as donors, private service providers and even non-governmental organisations (NGOs), to be included in the accountability process. ${ }^{108}$

The MDG framework was severely criticised for its lack of effective monitoring and accountability measures. With regard to the 2030 Agenda, the OHCHR is in agreement that an accountability mechanism which clearly outlines the duties of all states, developed and developing alike, and other relevant stakeholders, including international organisations, is necessary so as to avoid the mistakes of the MDGs. ${ }^{109}$ Not only obligations but also the purpose of and the means to exercise accountability measures must be objectively agreed upon, clearly defined and employed with an intention of empowerment of rights-holders. ${ }^{110}$ The measures outlined must adhere to internationally-agreed human rights standards. Moreover, it is of vital importance that access to justice and measures of redress must be equally available to all rights holders. ${ }^{111}$ States have the obligation to remove any economic or social barriers to access redress

$106 \operatorname{Knox}$ (n 27) 534-536.

$107 \mathrm{~K}$ Mechlem 'Food security and the right to food in the discourse of the United Nations' (2004) 10 European Law Journal 631 646; M Darrow \& A Tomas 'Power, capture, and conflict: A call for human rights accountability in development cooperation' (2005) 27 Human Rights Quarterly 471 512; UNDP 'Human rights and the Millennium Development Goals: Making the link' (2006) 23 http:// www.undp.org/content/dam/aplaws/publication/en/publications/poverty-reduct ion/poverty-website/human-rights-and-the-millennium-development-goals/Hum an\%20Rights\%20and\%20the\%20MDGs.pdf (accessed 18 February 2019). See also V Abramovich 'The rights-based approach in development: Policies and strategies' (2006) 88 CEPAL Review 45-47; P Uvin 'From the right to development to the rights-based approach: How "human rights" entered development' (2007) 17 Development in Practice 597603.

108 OHCHR 'Draft guidelines: A human rights approach to Poverty Reduction Strategies' (2002) para $230 \mathrm{https}$ //Www.refworld.org/pdfid/3f8298544.pdf (accessed 18 February 2019); OHCHR (n 102) 7; B O’Dwyer \& J Unerman 'Enhancing the role of accountability in promoting the rights of beneficiaries of development NGOs' (2010) 40 Accounting and Business Research 451454.

109 Pogge \& Sengupta (n 100) 573-574.

110 Darrow \& Tomas (n 107) 518-519.

111 CG Mokhiber 'Towards a measure of dignity: Indicators for rights-based development' (2001) 18 Statistical Journal of the United Nations Economic Commission for Europe 155 159. UNDG 'The human rights-based approach to 
mechanisms, and in some instances to provide legal services themselves. $^{112}$ It is essential to educate, build the capacity of and empower citizens to make use of accountability measures available to them to claim their rights. ${ }^{113}$ Moreover, transparency and access to high quality and disaggregated information is essential to ensure that citizens can make effective use of accountability measures.

Unfortunately, like its predecessor the 2030 Agenda is not legally binding. The Agenda, however, does require the creation of a 'robust follow-up and review mechanism to ensure that commitments are translated into time-bound results'. ${ }^{114}$ At the adoption of the goals it was agreed that the UN plays an important role in this regard. There was a strong call for relevant reforms and realignments in order to equip the organisation for this role. As mentioned above, under the Agenda a High-Level Political Forum must be established to review, through multi-stakeholder engagement, progress towards the achievement of the goals on an annual basis and give expression to the universal mandate of the new global partnership. ${ }^{115}$ Moreover, the Agenda calls for review processes at national, regional and global levels to ensure strengthened accountability to all citizens. ${ }^{116}$ The Agenda places on each government the primary duty for accountability, review and follow-up measures regarding development processes focused on the implementation of the goals. ${ }^{117}$ In this regard Goal 16 plays an essential role. Under this goal provision is made for the establishment of effective, accountable and inclusive institutions, the assurance of equal access to justice and access to all relevant information. Under Goal 17.8 UN member states have also highlighted the need for capacity building in data collection and 'improved, credible and realistic statistical data' to ensure an effective review and follow-up process. ${ }^{118}$ Provision is also made for the disaggregation of data according to the most significant grounds of discrimination. ${ }^{119}$ Moreover, para 74 of the Agenda provides clear

development cooperation: Towards a common understanding among UN agencies' (2003) $3 \mathrm{http}$ ://hrbaportal.org/the-human-rights-based-approach-todevelopment-cooperation-towards-a-common-understanding-among-un-agencies (accessed 18 February 2019).

112 Abramovich (n 107) 45.

113 UNDP (n 107) 24; O'Dwyer \& Unerman (n 108) 454; Van Ginneken (n 19) 113.

114 UN (n 34) 4. See also 2030 Agenda (n 2) para 72.

115 J Lee 'Common questions on the Sustainable Development Goals: What is the High-Level Political Forum on Sustainable Development? (United Nations Foundation) https://unfoundation.org/blog/post/common-questions-on-the-sus tainable-development-goals-what-is-the-high-level-political-forum-on-sustainabledevelopment/ (accessed 18 February 2019); M Halle \& R Wolfe 'Architecture for review and follow-up of the SDGs: Options for the High-Level Political Forum' (International Institute for Sustainable Development - Briefing Note 2015) 3 https://www.iisd.org/sites/default/files/publications/architecture-review-follow-upsdg-options-hlpf.pdf (accessed 18 February 2019).

1162030 Agenda (n 2) paras $47 \& 73$.

1172030 Agenda para 47.

118 UN (n 34) 4.

1192030 Agenda (n 2) para 48. 
principles to which all follow-up and review processes, irrespective of the level at which they take place, must adhere. ${ }^{120}$

As can be seen from the above, the 2030 Agenda is explicit in the accountability measures it requires and the guidelines that must be adhered to as required under a rights-based approach to development. Moreover, member states have committed themselves to making high-quality, reliable and properly disaggregated data available for these processes. However, even though the participation of all citizens in review processes is highlighted, no mention is made of building the capacity of rights holders to make use of mechanisms to hold duty bearers accountable. Reference is made only to building the capacities of development actors to meet their obligations, to take part in review processes and to establish accountability measures. The goals are also criticised for not sufficiently addressing the respective roles of all development actors and stakeholders in their implementation, which can hamper accountability measures. ${ }^{121}$ Moreover, the Agenda does not clearly articulate who is responsible for what which, as with the MDG framework, can place most of the burden on developing countries, in contradiction to the Agenda's statements on equality between countries. ${ }^{122}$

\subsection{Participation}

The principle of free, active and meaningful participation in all phases of the development process is based on the recognition of and respect for individual agency, as well as the right to have a say in decisions, in this case development objectives and processes, that affect one's life. Through participatory processes development actors must gain a better understanding of local contexts, the daily challenges faced by respective community members, as well as the possible negative effects related to proposed development strategies. All impacted individuals must be given the opportunity on an equal basis to express their needs and desires. Moreover, it is the duty of development actors to build the capacity of community members to effectively engage in participatory processes, which includes the obligation to make all relevant information available to all stakeholders. ${ }^{123}$ Development actors must be sensitive to any hindrances to equal participation, such as ensuring physical access to participatory spaces for the disabled and elderly.

As part of its means of implementation the Agenda proposes a 'revitalised Global Partnership' that will 'facilitate an intensive global engagement in support of implementation of all the goals and targets, bringing together governments, the private sector, civil

1202030 Agenda para 74.

121 Pogge \& Sengupta (n 100) 573.

122 See 2030 Agenda (n 2) para 13.

123 OHCHR (n 108); AA Frediani 'Sen's capability approach as a framework to the practice of development' (2010) 20 Development in Practice 173182. 
society, the United Nations system and other actors and mobilising all available resources' 124

Through the adoption of the goals, governments recognised that continued inclusiveness of all stakeholders is essential in achieving the goals. ${ }^{125}$ In order to achieve this the goals view access to information as essential. ${ }^{126}$ The Agenda also recognises the important contribution that NGOs, volunteers and private sector organisations and actors can make towards the achievement of the goals. Under the Agenda it is the duty of national governments to facilitate and coordinate their various contributions. According to Cazabat this is in line with the human development approach, which views development as coming from 'the people'. 12

The highly participatory and inclusive approach followed in the formulation of the goals must be commended. Moreover, a number of the goals are focused on ensuring equal participation of everyone in all spheres of life, namely, Goal 4, 'Ensure inclusive and equitable quality education and promote lifelong learning opportunities for all'; Goal 5.5, 'Ensure women's full and effective participation and equal opportunities for leadership at all levels of decision making in political, economic and public life'; and Goal 10.2, 'By 2030, empower and promote the social, economic and political inclusion of all, irrespective of age, sex, disability, race, ethnicity, origin, religion or economic or other status'. ${ }^{128}$ Furthermore, the Preamble to the Agenda refers to the participation of all stakeholders in mobilising the necessary means to implement the Agenda. ${ }^{129}$

Once again, the 2030 Agenda goes much further than the MDG framework which was viewed as an externally-driven and top-down development approach, formulated by government actors with limited input by NGOs and civil society organisations. Unfortunately, throughout the rest of the Agenda very little mention is made of the participation of local citizens and community members in national and local development processes geared towards the achievement of the SDGs. The focus largely is on the participation of duty bearers, such as various development actors, which include states, nongovernmental and civil society organisations, as well as private sector actors. Where mention is made of rights holders, the Agenda indeed makes provision for the equal participation of all persons and the requirement that all stakeholders should have access to all relevant information. However, except for the goals mentioned above, no other reference is made to building the capacities of community members to participate effectively and to be able to influence

1242030 Agenda (n 2) para 39. See also paras 60-71.

1252030 Agenda (n 2) para 3.

126 Cazabat (n 35) 30.

127 Cazabat 31. See also 2030 Agenda (n 2) para 52.

1282030 Agenda (n 2).

1292030 Agenda Preamble. 
decisions in the formulation, implementation and monitoring of development processes. Moreover, it is argued that the Agenda would have gone a long way towards implementing the principles of a rights-based approach to development if it explicitly stated the right to participation as an invaluable human right.

\subsection{Empowerment}

According to the principles of a rights-based approach to development all people must be empowered to demand development as a right, and become rights-holders with legitimate claims that can be enforced through accountability measures. It is the aim of the rights-based approach to development to expand the opportunities of people to meet their own needs by recognising their inalienable human rights. All people must be empowered through capacity building to take part, on an equal footing, in all phases of development.

As can be seen from the two parts above the empowerment of rights holders effectively to take part in participatory and accountability processes and to overcome social, economic and political barriers within these processes is very limited. The extent to which it features in the Agenda is limited to goals and targets that must be met, and not as an essential part of a means of implementation, monitoring and evaluation of development process. This reflects the greatest disconnect between the 2030 Agenda and the principles of a rights-based approach to development.

\subsection{Interrelatedness of human rights}

Under a rights-based approach to development the interrelatedness and interconnection of all human rights are emphasised. This means that all types of rights must be pursued under development processes to ensure the sustainability of these processes. As already stated, the formulated SDGs give expression to all types of human rights, including civil and political rights, which were not sufficiently addressed under the MDG framework. ${ }^{130}$ Moreover, the 2030 Agenda states that the SDGs are 'integrated and indivisible', giving expression to this essential principle of the rights-based approach to development. ${ }^{131}$ The goals also mimic the interrelatedness of various goals and relevant human rights as contained in the MDG framework, for example, goals on preventing malaria and other diseases and the right to health.

$130 \mathrm{OHCHR}$ (n 38).

1312030 Agenda (n 2) Preamble paras 5, 17, 18 \& 55; Nabarro (n 46) 24. 


\section{Conclusion}

In the final stages of the MDG framework, attention turned towards the development agenda that will succeed the initial goals. The UN and its member states, as well as various academics and practitioners, continuously called for the post-2015 agenda to be based on human rights. The 2030 Agenda for Sustainable Development signifies the next step forward in international development. Following on the 2000 MDG framework the new agenda aims to go further by addressing remaining development priorities and including all in development goals and processes. Based on the three pillars of sustainable development, namely, economic growth, social progress and environmental protection, the Agenda covers five categories of goals, namely, people, planet, prosperity, peace and partnership. Compared to the MDGs, the post-2015 framework therefore is much more comprehensive in the number of goals included, as well as the targets related to each goal. Moreover, the SDG framework is focused more on human development by being people-centred, gendersensitive and human rights-based.

It has been argued that a rights-based approach to development is best suited to answer the calls for a human rights-based post-2015 agenda. It thus fell to be examined to what extent all phases of the 2030 Agenda, which includes formulation, implementation, monitoring and evaluation, are guided by human rights standards and thus in line with a rights-based approach to development. It was determined that the goals and targets formulated under the Agenda do not sufficiently express a rights-based approach, as none of the SDGs is directly geared towards the protection, promotion, fulfilment of and respect for human rights. This failure proposed a second question for examination: Are the rest of the development phases under the 2030 Agenda in line with the principles of a rights-based approach to development and, if not, what can be done to rectify this?

As far as the principle of free, active and meaningful participation of all in development processes that affect people's lives is concerned, it was determined that the participation of local citizens in local development processes geared towards the achievement of the SDGs received very little attention. Moreover, insufficient reference is made to building the capacities of rights holders to effectively participate in these processes. The focus largely is on the participation of duty bearers. It has been argued that the Agenda could have gone a long way in implementing the principles of a rights-based approach to development if it explicitly had stated the right to participation as an invaluable human right. With regard to accountability, the 2030 Agenda is very clear on the necessity of effective accountability processes at all levels as well as the principles to which they must adhere. The need to support these processes through the availability of high-quality, reliable and properly disaggregated data is also 
highlighted. However, the goals have been criticised for not sufficiently addressing the respective roles of all development actors and stakeholders in the monitoring and evaluation of the goals contrary to the requirements of a rights-based approach to development. Moreover, as under the principle of participation, reference is made only to the capacities of development actors. References to building the capacities of rights holders to access and take part in accountability processes in an equal and effective manner are severely lacking. In contrast to the people-centred focus of a rights-based approach to development and the requirement of empowering rights holders, the means of implementation, monitoring and evaluation of the 2030 Agenda is focused much more on development actors than on the people it intends to assist. As far as the rest of the principles under a rights-based approach to development are concerned, namely, equality and non-discrimination and interrelatedness of rights, it may be argued that the Agenda gives sufficient expression to these principles although more still can be done to achieve the equality of all in development processes. Therefore, it may be concluded that although the 2030 Agenda in some areas is compatible with the principles of a rights-based approach to development, more should be done in the implementation, monitoring and evaluation of the SDGs to ensure that the full spectrum of advantages offered under a rights-based approach can be achieved. 